\title{
The Subocular Shelf of Fishes'
}

\author{
C. LAVETT SMITH AND REEVE M. BAILEY \\ Museum of Zoology, University of Michigan, Ann Arbor, Michigan
}

The subocular shelf is a bony lamina that extends inward from the suborbital bones of certain fishes and forms part of the wall of the orbit. Its presence or absence has long been used as a taxonomic character, particularly at the family level. Boulenger (1895) was apparently the first to introduce the character, and later ('04) he recorded its occurrence in the families of perciform fishes admitted by him. Smith ('41) used the subocular shelf to separate some pentapodid and related fishes. Recently Akazaki ('58) has described variations in the shelf among genera of sparoid fishes of Japan, and Katayama ('59, '60) has employed the configuration of the shelf to distinguish infrafamily groups of the Serranidae. It is apparent, however, that few authors have properly appreciated the utility of this character and it is commonly ignored.

The function of the shelf seems to have received little attention. Some authors dismiss it with the statement that it supports the eye, but the optical effectiveness of related fishes that lack the shelf invites reconsideration of this patent explanation. In an attempt to evaluate the taxonomic utility of the subocular shelf we have examined representatives of most of the currently recognized orders of fishes and have given considerable attention to the distribution of the shelf within the Perciformes and, particularly, among the families of the superfamily Percoidea. In this study it has been necessary to consider all bones of the circumorbital ring and in so doing we have developed what appears to be a satisfactory working hypothesis of the functional and phylogenetic significance of the subocular shelf.

\section{Nomenclature}

In primitive fishes the eye is completely surrounded by a series of small bones that may conveniently be referred to as the cir- cumorbital series. A further distinction is necessary, however, since the circumorbitals are readily divisible into (1) a supraorbital series consisting of bones that lie dorsal to the orbit and have no associated sensory canal and, (2) a suborbital series of bones that completes the circumorbital ring and is penetrated or traversed by the infraorbital branch of the sensory-canal system. The supraorbitals and suborbitals have very different evolutionary destinies.

There has been some variation in the method of counting the bones of the suborbital series. Most authors have included the first (anterior) bone, the lachrymal (preorbital), in the count, but some have excluded it and others have begun the count from the posterior side of the orbit. In the following discussion and descriptions the lachrymal bone, which in teleosts bears the anterior terminus of the infraorbital canal, is counted as the first member of the series. The count continues backward to include the dermosphenotic. At least among teleosts the number of bones in the suborbital series is remarkably constant: usually there are 6 , although in some fishes the bones have undergone reduction and in a few one or more of them have divided, thus increasing the total number of elements.

\section{Primitive fishes}

In such primitive fish groups as the paleoniscids, semionotids, and lepisosteids, the circumorbitals are connected to the surrounding dermal bones. The supraorbitals are rigidly attached to the cranium, and the suborbitals may either be in contact with the preopercle or separated from it by a series of postorbital bones. This closed bony sheathing of the circumorbital area is relatively inflexible. In the Jurassic

1 This study has been made possible by a research grant from the National Science Foundation (G-6368). 
semionotid Dapedium the circumorbitals approach uniformity in size and shape (fig. 1A). In Lepisosteus the anterior bones are modified in conjunction with the elongate snout (Gregory, '33: 128-129) and several bones correspond to the single lachrymal of teleosts. The infraorbital canal extends forward through them and the series of fixed maxillary bones to join its fellow from the opposite side in a supraethmoid (rostral) commissure, and to unite with the supraorbital canal posteromediad of the posterior nostril. In Polypterus the solidification of the suborbitals is extreme; the ventral elements behind the lachrymal are fused with the maxilla, and an anterior platelike extension of the preopercle covers the upper cheek and articulates with the dermosphenotic.

In the course of fish evolution there have been two prominent trends in the skull bones. The dermal bones have migrated inward so that they no longer present sculptured external surfaces and there has been reduction in size and increased mobility of the skull bones. The circumorbital bones have in general conformed to these trends except where environmental stresses have imposed additional demands that have been met by stiffening of the circumorbital ring.

In Amia calva (fig. 1B) the maxilla is freely movable and bears no canal. Perhaps partly in response to the loss of support from the maxilla and partly as protection for the critical joints at the proximal end of that bone, the anteriormost suborbital has become enlarged and modified as the lachrymal. The infraorbital canal extends forward from the lachrymal into the adnasal. The second and third suborbitals are small and slender but the fourth and fifth are much enlarged and extend backward nearly to the preopercle; the upper edge of suborbital 5 contacts the pterotic as well as the dermosphenotic. Amia lacks the supraorbital bones but this is probably a specialization since some fishes higher in the evolutionary series retain them. Occasionally there are a few bony nodules, "supplementary dermal bones," that appear to be vestigial postorbitals (Woodward, 1895: 369).

\section{Lower teleosts}

The primitive clupeiform Osteoglossum bicirrhosum (fig. 1C) has a suborbital series much like that of Amia, with the fourth and fifth bones greatly expanded to fill the entire region between the orbit and the preopercle and between the maxilla and the pterotic. Here also the supraorbitals are wanting and the frontal and dermosphenotic form the dorsal sector of the orbital rim. Gregory ('33: 163) identified the enlarged bone at the front of the orbit as a prefrontal. Since it is perforated by the infraorbital canal, however, we think that it is at least in part the lachrymal and that the suborbitals on Gregory's figure should be renumbered. The prefrontal in Osteoglossum is unossified or is coossified with the lachrymal. In the Salmonidae the skull is more mobile and there are two supraorbital bones; the lachrymal is attached to the anterior of these rather than to the prefrontal. All of the suborbitals are thin and delicate, and the only contact with the neurocranium is between the dermosphenotic and the sphenotic. In the Salmoninae the dermosphenotic is unossified. The posterior suborbitals may be in contact with or remote from the preopercle.

Some characids have a large supraorbital that meets the dermosphenotic to exclude the frontal from the orbital rim, as in Hydrocyon and Brycon (Gregory, '33: 184-185), or the supraorbital may be absent, as in Erythrinus (Gregory, '33: 182) and Carnegiella (Weitzman, '54: 249). In the three genera first named the suborbitals are large plating bones that fully sheath the cheek; in Carnegiella they are much reduced. The bone termed adnasal by Weitzman seems to be the lachrymal; although not shown in his figure, it bears a tube of the infraorbital canal.

In most cyprinids (fig. 1D) and in the more generalized genera of the Catostomidae, the prefrontal provides the sole osseus support of the anterior suborbitals, and posteriorly only the dermosphenotic is in contact with the skull. There is a single large supraorbital bone. In the more advanced catostomids (Catostominae) the supraorbital is lacking, being fully coossified with the frontal (Weisel, '60: 110). In the ictalurid catfishes the lachry- 
mal is a small, Y-shaped bone and the remaining 5 or 6 suborbitals are reduced to slender tubular ossifications around the infraorbital canal. In the Ictaluridae there is no supraorbital.

Throughout the Clupeiformes and the Cypriniformes modifications serve to make the suborbital series more flexible. The bones are reduced in size, the connections between them are ligamentous, and the diarthrosis between the lachrymal and the prefrontal is developed to allow movement in any plane. The lachrymal has been specialized to protect the anterior end of the maxilla. At the same time the trend in the supraorbitals is toward reduction, loss, or fusion so that the dorsal rim of the orbit is rigid. No malacopterygian is known to have a subocular shelf.

\section{Development of the shelf}

In the Beryciformes there is a temporary reversal of the trend toward increasing flexibility of the circumorbital ring. Part of the resultant stiffening is achieved through the development of sutures between the individual suborbital bones. A more important bracing device is evolved through the expansion of sorne of the suborbital bones to provide structural strengthening and additional area for the attachment of connective tissues. This expansion of the bones has taken place in the only direction possible - inward. In the process the suborbital ring has been converted from a flat chain to a series of inflexible bones that are $L$-shaped in cross section. This interpretation explains the presence of the subocular shelf as a response to the need for mechanical strengthening of the entire complex of structures in the subocular area rather than for simple support of the eyeball. Further evidence to discredit the latter hypothesis is provided by the snakehead, Channa (commonly known as Ophicephalus). In this genus the welldeveloped shelf lies on the posterior face rather than the floor of the orbit (Day, '14: 26).

The subocular shelf first appears in the beryciform fishes and seems to be confined to the orders Beryciformes and Perciformes. In Myripristis microphthalmus (fig. 1E) the shelf is made up of segments derived from bones two through five of the suborbital series. This seems to be the primitive condition but through selective loss and retention of elements the shelf has assumed modified forms in various fish groups. In the beryciform Monocentris japonicus (Starks, '04: 618), as in most members of the perciform superfamily Percoidea, the third bone alone contributes to the shelf. The third suborbital is nearly always involved and this is perhaps presaged in Myripristis where the segment of the shelf derived from the third bone is the widest. In Channa lucius the third suborbital enters the shelf but the fourth and fifth, which contribute equally, form most of the shelf, which consequently forms the posterior wall of the orbit. In Channa striata only the fourth and fifth suborbitals participate in the shelf, but the fifth is much the larger (fig. 3R). In Scorpaenidae and Mullidae the second and third bones contribute the shelf. These variations seem readily derivable from the unmodified shelf in Myripristis, a finding that is consistent with the hypothesis that the beryciform fishes are on or near the stem line leading to the Perciformes and their derivatives.

In the climbing perch, Anabas testudineus, of the order Perciformes, suborbitals two through five contribute to a shelf that lines both the inferior and posterior walls of the orbit. Suborbitals three to five form a wide, stiff plating over the cheek and buttress the preopercle. The well-developed shelf, which is perhaps in part a secondary elaboration, seems here to provide effective strengthening for the expanded suborbitals. These in turn contribute bracing for the opercular bones that are modified to assist in terrestrial locomotion (Norman, '31: 46).

\section{Variations and modifications in the subocular shelf}

Although systematists have largely confined their utilization of the subocular shelf to statements as to its presence or absence in particular families, study of its structural variations (1) demonstrates that much greater use can be made of the shelf as a taxonomic character, and (2) adds confirmation to the hypothesis that the shelf is a stiffening brace. 
In its most common form the shelf is derived from the third suborbital only, is roughly semicircular in outline, and is slightly concave to conform to the contour of the orbit. The shelf is commonly longer than the exposed part of the bone so that it overlaps the second and fourth suborbitals. The red hind, Epinephelus guttatus (fig. 1F), and the bigeye, Priacanthus arenatus (fig. 2G), illustrate this condition in species with broad and narrow preorbital regions, respectively. In the freshwater drum, Aplodinotus grunniens (fig. $2 \mathrm{H})$, the shelf is reduced to a narrow, fingerlike process and the lateral faces of the suborbitals are broad, thin plates, thickened along the orbital margin and strengthened by a radial series of narrow bridges to provide protection for the infraorbital canal.

Three major trends in the structure of the shelf and the supporting bones have been discerned in this survey. These are: (1) increased bracing of the suborbital ring leading to secondary contact between the suborbitals and the neurocranium or the palato-quadrate arch, (2) complete (secondary) loss of the shelf, and (3) utilization of the shelf for muscle attachment. These are considered with selected examples below. Additional trends will doubtless be found when other specialized groups of fishes are studied carefully.

Increased bracing of the suborbital series. Additional stiffening of the suborbitals may be achieved through modification of the articulation between the lachrymal and the prefrontal, as seen in Scatophagus argus (fig. 2I). In this species a stout peg of bone that extends inward articulates firmly along its entire dorsal face with the ventral surface of the prefrontal. Anteriorly the lachrymal articulates with the palatine and posteriorly it is completely fused with the second suborbital, which in turn is rigidly sutured to the third suborbital. In the wolf-eel, Anarrhichthys ocellatus, the suborbital bones are massive, and a mesial shelflike projection derived from the first two bones articulates firmly with the prefrontal. It is not certain that this structure is homologous with the usual perciform shelf. These adaptations effectively limit motion between the lachrymal and the prefrontal, and allow little movement of the entire suborbital series.

In the snook, Centropomus undecimalis (fig. $2 \mathrm{~J}$ ), the shelf gives rise to a posterior bony process that connects by ligament to the anterior edges of the hyomandibular and the metapterygoid. The process and its ligament thus serve as a guy to steady the suborbital ring. A similar but shorter process is found in Roccus chrysops.

In the sparid Calamus calamus (fig. $2 \mathrm{~K}$ ) the shelf has an anterior process that joins the prefrontal. Here also the articulation between lachrymal and prefrontal is modified to limit motion to a hinge line. Calamus is a deep-headed form and the lachrymal is much enlarged to cover the preorbital region.

A similar arrangement is found in the pomacentrid Hypsypops rubicundus (fig. 2L). Suborbitals two through five contribute to the shelf but the segment derived from the third bone is the largest and is provided with a knob that extends inward to articulate with a complex process of the palatoquadrate mechanism. This process is formed by the palatine, ectopterygoid, and mesopterygoid, but the only contact is with the mesopterygoid. Again the lachrymal-prefrontal joint is a hinge that allows little movement.

Secondary loss of the subocular shelf. Within the superfamily Percoidea a few families have no trace of the subocular shelf. Because there is an apparent correlation between the absence of the shelf and the habitat occupied by most members of the family we believe that loss of the shelf is a specialization. The families that lack the shelf are not particularly closely related and do not form a single phyletic line, so it is evident that this specialization must have been derived independently several, perhaps many, times.

Certain long-established families of freshwater fishes have lost the shelf: the Centrarchidae, Percidae, Cichlidae, and Toxotidae are examples. In the largemouth bass, Micropterus salmoides (fig. $3 \mathrm{M}$ ), the loss of the shelf is not the only modification leading to mobility of the suborbital ring since the second and third suborbitals are subdivided and the connections between the bones are diarthroses, affording maximum flexibility. Even more 
extreme is the situation in the white crappie, Pomoxis annularis (fig. $3 \mathrm{~N}$ ), in which the second bone has been lost, leaving an interrupted infraorbital canal and an incomplete suborbital ring. Possibly the shelf has been lost in freshwater fishes in response to the need for an efficient gill pump in an environment subject to occasional periods of oxygen deficit. The Nandidae, Channidae, and Anabantidae constitute exceptions in that they are freshwater groups that retain the shelf.

A second group of families that lack the shelf contains fishes adapted for a midwater or pelagic existence: the Rachycentridae, Coryphaenidae, Bramidae, and $\mathrm{Ky}-$ phosidae are examples. In suborders of the Perciformes other than the Percoidei, the Scombridae, Stromateidae and Mugilidae also fall into this category. Perhaps the demands of respiration or of predaceous or piscivorous habits necessitate a flexible suborbital ring.

The third group in which there is no subocular shelf includes those families which have specializations of the mouthparts that require exceptional mobility. The Leiognathidae and the Gerridae have extremely protrusible mouths. Except in the gerrid genus Diapterus the shelf is lacking. In at least some species of Pomadasyidae (e.g., Haemulon sciurus, fig. 30), the mouth is modified so that it can be opened widely to display its red lining. Apparently correlated modifications include the loss of the subocular shelf and the presence of a true diarthrosis between the palatine and pterygoid bones. The labrids and scarids, with protrusible mouths or parrotlike beaks, also lack the shelf.

Utilization of the shelf for muscle attachment. In most species with a subocular shelf no major muscles are attached to it, but in a few forms the shelf has secondarily been taken over for the origin of a muscle. In the snapper Lutjanus blackfordi (fig. 3P) the lachrymal is wide and covers the shaft of the maxilla; the shelf is roughly quadrangular and overlaps the fourth suborbital but not the second. There is a flexible ligamentous connection between the second and third suborbitals. The dorsal portion of the adductor mandibulae originates on the ventral surface of the subocular shelf. In order to compensate for the muscle pull there is a ligament connecting the fourth and fifth bones with the hyomandibular. Thus, there is a direct line of stress from the hyomandibular, through the ligament, the fifth suborbital, the fourth suborbital, the shelf, and the muscle from its origin to its insertion on the inner face of the proximal end of the maxilla.

In the black jack, Caranx lugubris (fig. $3 Q$ ), there is an apparent independent development of the shelf as an origin for the adductor mandibulae muscle. In a sense, this species appears to be subjected to conflicting demands. It retains the shelf of its more sedentary ancestors and needs a brace for the shelf to counteract the pull of the muscle. At the same time the jack is adapted for a midwater existence that requires a flexible suborbital ring. It has been successful in meeting both conditions: the brace is a splint of bone from the shelf that articulates with the hyomandibular; the flexibility is achieved by the development of diarthroses between the individual bones of the suborbital series.

There is a more notable specialization in the spotted goatfish, Pseudupeneus maculatus, in which the anteroventral shelf is derived from the second and third suborbitals. The long narrow lachrymal, which bears numerous branches of the infraorbital canal, is excluded from the orbital margin. Two dorsal bundles of the adductor mandibulae insert together on the maxilla; the dorsal one originates on the shelf of the enlarged second suborbital, the one below passes directly beneath the third suborbital to its tendonous origin on the hyomandibular. This tendon is attached by many small muscle fibers to the shelf of the third suborbital. Here, the strain produced by the contraction of the upper segment is counteracted by the tendon of the lower.

In Channa it is the levator arcus palatini muscle that is attached to the subocular shelf, morphologically a postocular shelf (fig. 3R; see p. 3). In this genus the postorbital part of the head is excessively elongate to accommodate a suprabranchial respiratory chamber. In conjunction with this modification the head of the hyoman- 
dibular is greatly lengthened and an extension of the anterior portion of the levator arcus palatini originates on that segment of the shelf derived from the fifth suborbital. The muscle inserts on the metapterygoid. In Channa the suborbitals are unusually deep and thick and are broadly laminated to produce a shield that is rigid in the sagittal axis but semiflexible in a horizontal plane. In the distantly related anabantid Anabas testudineus (see p. 3) the suprabranchial chamber is provided with an elaborate labyrinthine apparatus for aerial respiration. In this form, however, the head is not notably elongate, and the levator arcus palatini does not attach to the shelf.

\section{Occurrence of the subocular shelf}

As indicated above, we have not found a subocular shelf in any primitive fish or in any lower teleost. Nor have we discovered a shelf in representatives examined from such "intermediate" orders as the Beloniformes (Belonidae, Exocoetidae), Notacanthiformes (Notacanthidae, Boulenger, '04: 624), Cyprinodontiformes (Cyprinodontidae, Poeciliidae), Gadiformes (Gadidae), Gasterosteiformes (Gasterosteidae), Pegasiformes (Pegasidae), Lampridiformes (Lampridae), Zeiformes (Zeidae), and Percopsiformes (Percopsidae, Aphredoderidae ).

In the Beryciformes a subocular shelf is present in the three species of the suborder Berycoidei that were examined: Polymixia japonica Günther [Polymixiidae], Holocentrus rufus (Walbaum) and Myripristis microphthalmus Bleeker [Holocentridae]. Hoplostethus japonicus Hilgendorf [Trachichthyidae] and Monocentris japonicus (Houttuyn) [Monocentridae] are also reported to have a shelf (Starks, '04: 606, 618). There is no shelf, however, in the bathypelagic species Melamphaes bispinosus Gilbert [Melamphaeidae] of the suborder Anoplogasteroidei. In this species the thin, delicate suborbitals are much modified and are expanded laterally as a partial protective support for the infraorbital canal.

It is in the order Perciformes that the subocular shelf reaches its best development. Many hundreds of species have a shelf and its presence or absence is of marked utility in classification and in revealing phyletic trends. The number of kinds examined is not exhaustive so a shelf may have been overlooked in certain groups in which it is present in some forms. Nevertheless, the distribution is probably rather well indicated. Among the groups commonly classified as suborders of the Perciformes we have failed to find a shelf in any of the following: Siganoidei, Kurtoidei (Boulenger, '04: 688), Trichiuroidei, Scombroidei, Gobioidei, Callionymoidei, Ophidioidei, Stromateoidei, and Mugiloidei. As indicated above ( $p$. 3) a well-defined shelf is present in Channa and in Anabas (Anabantoidei). We have examined only two genera among the Blennioidei. In Labrisomus the shelf, if present, is narrow; that in Anarrhichthys has been discussed (p. 4). In the Acanthuroidei, sometimes placed in the Percoidei, we find a shelf in Zanclus (Zanclidae) but not in Acanthurus, Ctenochaetus, or Zebrasoma (Acanthuridae). Among representatives of the Cottoidei examined, the shelf is present (Sebastes) or absent (Scorpaena) in the Scorpaenidae, and absent in the Cottidae, Anoplopomatidae, and Hexagrammidae. The majority of the percoid fishes are in the suborder Percoidei, a group in which the shelf is commonly present but has presumably been lost repeatedly in separate phyletic lines. In the Carangidae, Emmelichthyidae, Ephippidae, Gerridae, Pempheridae and Sparidae some genera have the shelf and others lack it. More commonly, however, all forms in a single family agree. The species of the order Perciformes that have been examined for presence or absence of a subocular shelf are listed, by family, in table 1.

Among the orders derived from the Perciformes, none is known to have a subocular shelf. For several of these the species studied lack suborbital bones altogether or retain only a reduced lachrymal: Pleuronectiformes, Bothus lunatus (Linnaeus), Parophrys vetulus Girard; Tetraodontiformes, Rhineacanthus aculeatus (Linnaeus), Balistes sp.; Gobiesociformes, Gobiesox sp. (Gregory, '33: 372); Batrachoidiformes, Opsanus tau (Linnaeus); Lophiiformes, Histrio histrio (Linnaeus); Mastacembeliformes, Macrognathus acu- 
TABLE 1

The subocular shelf in fishes of the order Perciformes. To facilitate reference the sequence is alphabetical. Presence of a shelf is indicated by $(+)$, absence by $(0)$.

\begin{tabular}{|c|c|c|c|}
\hline Family - Species & $\begin{array}{c}\text { Subocular } \\
\text { shelf }\end{array}$ & Species & $\begin{array}{l}\text { Subocular } \\
\text { shelf }\end{array}$ \\
\hline Acanthuridae & & Chiasmodontidae & \\
\hline Acanthurus coeruleus Bloch and & & Chiasmodon niger Johnson & 0 \\
\hline Schneider & 0 & (Norman, '29: 532-533) & \\
\hline A. matoides Valenciennes & $\mathbf{0}$ & Cichlidae & \\
\hline A. triostegus (Linnaeus) & 0 & Cichlasoma cyanoguttatum (Baird & \\
\hline Ctenochaetus striatus (Quoy and & & and Girard) & 0 \\
\hline Gaimard) & 0 & C. biocellatum (Regan) & 0 \\
\hline Zebrasoma flavescens (Bennett) & 0 & Geophagus jurupari Heckel & 0 \\
\hline Ammodytidae & & Haplochromis strigigena (Pfeffer) & 0 \\
\hline Ammodytes hexapterus Pallas & 0 & Petenia splendida Günther & $\mathbf{0}$ \\
\hline Anabantidae & & Pterophyllum eimekei Ahl & 0 \\
\hline Anabas testudineus (Bloch) & + & Tilapia zilli (Gervais) & 0 \\
\hline Anarhichadidae & & Cirrhitidae & \\
\hline Anarrhichthys ocellatus Ayres & (see text) & Cirrhitus alternatus Gill & + \\
\hline Anoplopomatidae & & Paracirrhites arcatus (Cuvier) & + \\
\hline Anoplopoma fimbria (Pallas) & 0 & Clinidae & \\
\hline Apogonidae & & Labrisomus nuchipinnis (Quoy & \\
\hline Apogon conklini (Silvester) & + & and Gaimard) & 0 \\
\hline A. lineatus Temminck and Schlegel & + & Coryphaenidae & \\
\hline A. stellatus (Cope) & + & Coryphaena hippurus Linnaeus & 0 \\
\hline Arripidae & & Cottidae & \\
\hline Arripis trutta (Forster) & + & Cottus cognatus Richardson & $\mathbf{0}$ \\
\hline Banjosidae & & C. ricei (Nelson) & 0 \\
\hline Banjos banjos (Richardson) & + & Scorpaenichthys marmoratus (Ayres) & 0 \\
\hline Bathyclupeidae & & Dichistiidae & \\
\hline $\begin{array}{l}\text { Bathyclupea argentea Goode and } \\
\text { Bean }\end{array}$ & + & $\begin{array}{l}\text { Dichistius sp. } \\
\text { (Norman, MS.) }\end{array}$ & + \\
\hline Bramidae & & Drepanidae & \\
\hline Brama rayi (Bloch) & 0 & Drepane punctata (Linnaeus) & 0 \\
\hline Branchiostegidae & & Eleotridae & \\
\hline Caulolatilus princeps (Jenyns) & + & Eleotris pisonis (Gmelin) & $\mathbf{0}$ \\
\hline Malacanthus plumieri (Bloch) & + & Embiotocidae & 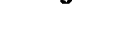 \\
\hline Callionymidae & & Cymatogaster aggregata Gibbons & + \\
\hline Callionymus richardsoni Bleeker & 0 & Embiotoca jacksoni Agassiz & + \\
\hline Carangidae & & Hysterocarpus traski Gibbons & + \\
\hline Caranx latus Agassiz & + & Emmelichthyidae & -1 \\
\hline C. lugubris Poey & + & Centracanthus cirrus Rafinesque & + \\
\hline Selene vomer (Linnaeus) & 0 & Dipterygonotus gruveli Chabanaud & + \\
\hline Seriola falcata Valenciennes & + & Emmelichthyops atlantica Schultz & $a$ \\
\hline Centrarchidae & & Erythrocles schlegeli (Günther) & + \\
\hline 13 species in genera Acantharchus, & & Merolepis vulgaris (Valenciennes) & + \\
\hline Ambloplites, Archoplites, & & Enoplosidae & \\
\hline Chaenobryttus Enneacanthus, & & Enoplosus armatus (White) & + \\
\hline $\begin{array}{l}\text { Lepomis, Micropterus, and } \\
\text { Pomoxis }\end{array}$ & & Ephippidae & \\
\hline $\begin{array}{l}\text { Pomoxis } \\
\text { Centropomidae }\end{array}$ & 0 & Chaetodipterus faber (Broussonet) & 0 \\
\hline & & Ephippus orbis (Bloch) & + \\
\hline $\begin{array}{l}\text { Centropomus undecimalis (Bloch) } \\
\text { Cepolidae }\end{array}$ & + & $\begin{array}{l}\text { Gerridae } \\
\text { Diapterus olisthostomus (G }\end{array}$ & \\
\hline Acanthocepola krusensterni (Tem- & & $\begin{array}{l}\text { Diapterus otisthostomus (Goode and } \\
\text { Bean) }\end{array}$ & + \\
\hline minck and Schlegel) & + & D. plumieri (Cuvier) & + \\
\hline Cepola rubescens Linnaeus & + & Eucinostomus argenteus Baird and & \\
\hline Chaetodontidae & & Girard & $\mathbf{0}$ \\
\hline Chaetodon aya Jordan & + & Gerres cinereus (Walbaum) & 0 \\
\hline C. striatus Linnaeus & + & Girellidae & 0 \\
\hline Chelmon rostratus (Linnaeus) & + & Girella nigricans (Ayres) & + \\
\hline Holacanthus bermudensis (Goode) & + & Gobiidae & \\
\hline Pomacanthus aureus (Bloch) & + & Awaous transandeanus (Günther) & 0 \\
\hline Channidae & & Hexagrammidae & \\
\hline Channa lucius (Kuhl and van & & Ophiodon elongatus Girard & 0 \\
\hline Hasselt) & + & Histiopteridae & \\
\hline C. striata (Bloch) & + & Quinquarius japonicus (Doderlein) & + \\
\hline
\end{tabular}


TABLE 1 (Continued)

\begin{tabular}{|c|c|c|c|}
\hline Species & $\begin{array}{l}\text { Suboculax } \\
\text { shelf }\end{array}$ & Species & $\begin{array}{c}\text { Subocular } \\
\text { shelf }\end{array}$ \\
\hline \multicolumn{2}{|l|}{ Kuhliidae } & \multicolumn{2}{|l|}{ Pempheridae } \\
\hline Kuhlia malo (Valenciennes) & $\mathbf{0}$ & Pempheris oualensis Cuvier & + \\
\hline K. marginata (Cuvier) & 0 & P. schomburgki Müller and Troschel & 0 \\
\hline K. rupestris (Lacépède) & 0 & Percidae & \\
\hline \multicolumn{2}{|l|}{ Kurtidae } & Etheostoma blennioides Rafinesque & 0 \\
\hline \multirow{2}{*}{\multicolumn{2}{|c|}{$\begin{array}{l}\text { Kurtus indicus Bloch } \\
\quad \text { (Boulenger,'04: 688) }\end{array}$}} & E. simoterum (Cope) & 0 \\
\hline & & Perca flavescens (Mitchill) & $\mathbf{0}$ \\
\hline \multicolumn{2}{|l|}{ Kyphosidae } & Percina maculata (Girard) & $\mathbf{0}$ \\
\hline \multicolumn{2}{|l|}{ Hermosilla azurea Jenkins and } & Stizostedion canadense (Smith) & $\mathbf{0}$ \\
\hline Evermann & $\mathbf{0}$ & S. vitreum (Mitchill) & $\mathbf{0}$ \\
\hline Kyphosus sectatrix (Linnaeus) & 0 & Plesiopidae & \\
\hline \multicolumn{2}{|l|}{ Labracoglossidae } & Plesiops melas Bleeker & + \\
\hline Labracoglossa argentiventris Peters & + & P. nigricans (Rüppell) & + \\
\hline \multicolumn{2}{|l|}{$\begin{array}{l}\text { Labridae } \\
\text { Bodianus rufus (Linnaeus) }\end{array}$} & Polynemidae & \\
\hline Bodianus rufus (Linnaeus) & $\begin{array}{l}0 \\
0\end{array}$ & $\begin{array}{l}\text { Polydactylus octonemus (Girard) } \\
\text { Pomacentridae }\end{array}$ & + \\
\hline $\begin{array}{l}\text { Coris gaimardi (Quoy and Gaimard) } \\
\text { Halichoeres radiatus (Linnaeus) }\end{array}$ & $\begin{array}{l}0 \\
0\end{array}$ & Chromis punctipinnis (Cooper) & + \\
\hline Lachnolaimus maximus (Walbaum) & 0 & Hypsypops rubicundus (Girard) & + \\
\hline Pimelometopon pulchrum (Ayres) & 0 & Pomadasyidae & \\
\hline \multirow{2}{*}{\multicolumn{2}{|c|}{$\begin{array}{l}\text { Lactariidae } \\
\text { Lactarius lactarius (Bloch and }\end{array}$}} & Anisotremus davidsoni (Steindachner) & $\mathbf{0}$ \\
\hline & & A. surinamensis (Bloch) & $\mathbf{0}$ \\
\hline & 0 & Conodon serrifer Jordan and Gilbert & 0 \\
\hline & Haemulon plumieri (Lacépède) & 0 \\
\hline \multirow{2}{*}{\multicolumn{2}{|c|}{$\begin{array}{l}\text { Gazza minuta (Bloch) } \\
\text { Leiognathus nuchalis (Temmick and }\end{array}$}} & $\begin{array}{l}\text { H. sciurus (Shaw) } \\
\text { Orthopristis chrysopterus (Linnaeus) }\end{array}$ & $\begin{array}{l}0 \\
0\end{array}$ \\
\hline & 0 & Plectorhinchus cinctus (Temminck & \\
\hline L. ruconius (Hamilton-Buchanan) & 0 & and Schlegel) & 0 \\
\hline & $\begin{array}{l}\text { Pomadasys crocro (Cuvier) } \\
\text { Pomatomidae }\end{array}$ & 0 \\
\hline & $\mathbf{0}$ & & \\
\hline Lobotes surinamensis (Bloch) & 0 & us saltatrix (Linnaeus) & + \\
\hline \multicolumn{2}{|l|}{ Lutjanidae } & $\begin{array}{l}\text { Scombrops boops } \\
\text { Priacanthidae }\end{array}$ & + \\
\hline \multirow{2}{*}{\multicolumn{2}{|c|}{$\begin{array}{l}\text { Caesio chrysozona Cuvier } \\
\text { C. lunaris Cuvier }\end{array}$}} & & \\
\hline & & $\begin{array}{l}\text { Priacanthus arenatus Cuvier } \\
\text { Rachycentridae }\end{array}$ & + \\
\hline \multicolumn{2}{|l|}{$\begin{array}{l}\text { Lutjanus apodus (Walbaum) } \\
\text { L. blackfordi Goode and Bean }\end{array}$} & $\begin{array}{l}\text { Rachycentron canadum (Linnaeus) } \\
\text { Scaridae }\end{array}$ & $\mathbf{0}$ \\
\hline \multirow{3}{*}{$\begin{array}{l}\text { L. griseus (Linnaeus) } \\
\text { L. vivanus (Cuvier) } \\
\text { Ocyurus chrysurus (Bloch) } \\
\text { Rhomboplites aurorubens (Cuvier) }\end{array}$} & $\stackrel{t}{+}$ & Scarus guacamaia Cuvier & 0 \\
\hline & $\begin{array}{l}+ \\
+\end{array}$ & S. oviceps Valenciennes & 0 \\
\hline & + & $\begin{array}{l}\text { Sparisoma rubripinne (Valenciennes) } \\
\text { Scatophagidae }\end{array}$ & 0 \\
\hline \multirow{2}{*}{\multicolumn{2}{|c|}{$\begin{array}{l}\text { Menidae } \\
\text { Mene maculata (Bloch and }\end{array}$}} & $\begin{array}{l}\text { Scatophagidae } \\
\text { Scatophagus argus (Linnaeus) }\end{array}$ & + \\
\hline & & Sciaenidae & + \\
\hline \multicolumn{2}{|l|}{$\begin{array}{l}\text { Schneider) } \\
\text { Monodactylidae } \\
\text { Monodactulus argenteus (Linnaeus) }\end{array}$} & Aplodinotus grunniens Rafinesque & + \\
\hline & + & Cynoscion nobilis (Ayres) & + \\
\hline \multicolumn{2}{|l|}{$\begin{array}{l}\text { Mugilidae } \\
\text { Mugil curema Valenciennes }\end{array}$} & Equetus lanceolatus (Linnaeus) & \\
\hline Mugil curema Valenciennes & $\mathbf{0}$ & Menticirrhus undulatus (Girard) & $\begin{array}{l}+ \\
+\end{array}$ \\
\hline Mullidae & & Scombridae & \\
\hline $\begin{array}{l}\text { Mulloidichthys martinicus (Cuvier) } \\
\text { Pseudupeneus maculatus (Bloch) }\end{array}$ & + & $\begin{array}{l}\text { Auxis tapeinosoma Bleeker } \\
\text { Sarda sarda (Bloch) }\end{array}$ & 0 \\
\hline Nandidae & & Scomber scombrus Linnaeus & $\mathbf{0}$ \\
\hline $\begin{array}{l}\text { Polycentrus schomburgki (Müller } \\
\text { and Troschel) }\end{array}$ & + & $\begin{array}{l}\text { Scomberomorus regalis (Bloch) } \\
\text { Scorpaenidae }\end{array}$ & 0 \\
\hline Pristolepis fasciatus (Bleeker) & $\dot{t}$ & Scorpaena guttata Girard & 0 \\
\hline Nototheniidae & & Sebastes atrovirens (Jordan and & \\
\hline Notothenia macrocephala Günther & 0 & Gilbert) & \\
\hline Opisthognathidae & & S. diploproa (Gilbert) & + \\
\hline Opisthognathus maxillosus Poey & 0 & S. entomelas (Jordan and Gilbert) & + \\
\hline Oplegnathidae & & S. goodei (Eigenmann and & \\
\hline Oplegnathus fasciatus (Temminck & & Eigenmann) & \\
\hline and Schlegel) & + & S. paucispinis Ayres & + \\
\hline O. punctatus (Temminck and & & S. rhodochloris (Jordan and Gilbert) & + \\
\hline Schlegel) & + & S. serriceps (Jordan and Gilbert) & \\
\hline
\end{tabular}


TABLE 1 (Continued)

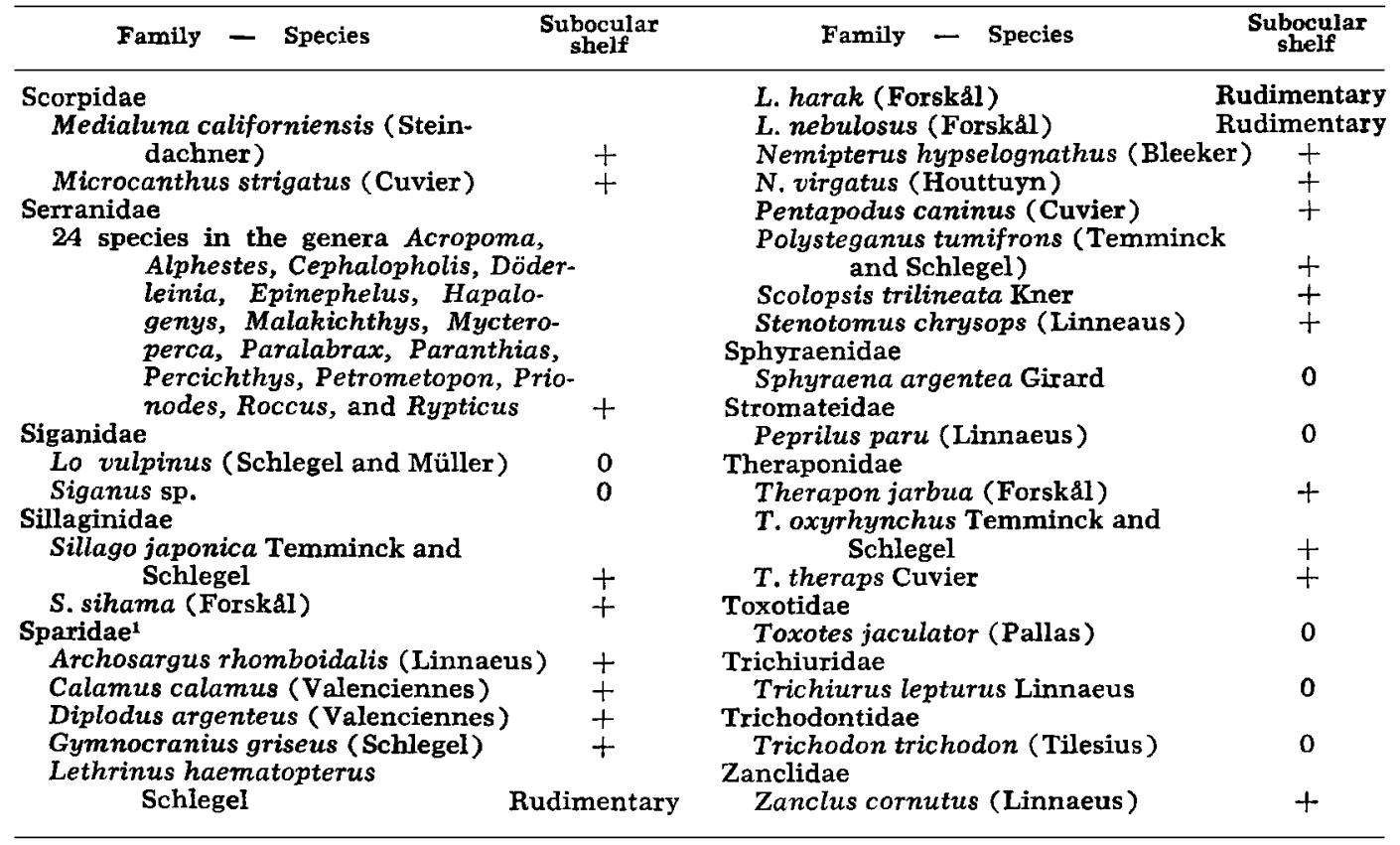

1 The genera here assigned to the Sparidae, together with certain related groups, have an unsettled family history, many having been juggled freely among the Denticidae, Lethrinidae, Lutjanidae, Nemipteridae, Pentapodidae, Pomadasyidae, and Scolopsidae. On the basis of work still incomplete these genera seem best associated in a single family. In view of the vagaries and inconsistencies of prior classifications, adoption of this provisional arrangement is deemed preferable to acceptance of any of the older schemes, all of which are demonstrably imperfect.

leatus (Bloch); Synbranchiformes, Fluta alba (Zuieuw). In Remora remora (Linnaeus), of the order Echeneiformes, the suborbital series is of a generalized percoid type, with 6 bones; there is no subocular shelf.

\section{DISCUSSION}

If it is correct that the suborbitals are modified as an indirect response to the environment, it appears that selection for and against the presence of the shelf is extremely slow. This suggests that the survival value of the shelf, though slight, is still present. Then it follows that the shelf is indicative of the phyletic history of the group. For example, strictly freshwater serranids still retain the large shelf of their marine ancestors, as does the only residual freshwater embiotocid, Hysterocarpus traski.

The freshwater sciaenid Aplodinotus grunniens has a slender shelf and one might suspect that it is being lost. But other sciaenids also have a slender shelf (e.g., Cynoscion nobilis, Menticirrhus undulatus). Most sciaenids, however, inhabit estuaries or other euryhaline waters. A truly marine species, Equetus lanceolatus, has a slightly larger shelf but it still is not as well developed as in groups having a long oceanic history. It is inviting to speculate, then, that Equetus has inhabited the sea longer than Aplodinotus has lived in fresh water. In the light of this reasoning one may suspect that nandids are recent invaders of fresh water, for in Pristolepis fasciata the shelf is well developed.

The posterior shelf of Channa is apparently related to the development of the suprabranchial chamber. Thus, its presence facilitates aerial respiration.

\section{SUMMARY}

The subocular shelf is interpreted as a mechanism for stiffening the suborbital ring. It apparently developed first in the Beryciformes with bones two through five of the suborbital series contributing to the 
shelf. Through selective modification and loss of elements the shelf has assumed diverse form in various groups of perciform fishes. Structural change of the shelf and associated parts has proceeded in several directions - additional bracing through contact with the skull or the palatoquadrate arch, reduction or complete loss, and utilization as a muscle origin. Complete loss of the shelf has occurred in several freshwater families, in midwater and pelagic fishes, and in fishes with specialized mouthparts for which additional flexibility is required. Loss of the suborbitals or failure of ossification is a frequent specialization in perciforms and their derivatives.

The subocular shelf is usually a consistent taxonomic character at the family level, but in a few families some forms have and others lack the shelf. Those known to us are the Carangidae, Emmelichthyidae, Ephippidae, Gerridae, Pempheridae, Scorpaenidae, and Sparidae. Modifications in the shape or structural composition of the shelf may prove useful either at infrafamily or suprafamily levels. There is indication that changes in the form of the shelf take place slowly and that the shelf may serve as an indicator of phyletic history.

\section{LITERATURE CITED}

Akazaki, M. 1958 Studies on the orbital bones of sparoid fishes. Zool. Mag. (Dobutsugaku Zasshi), 67: 322-325 (in Japanese, with English résumé).

Boulenger, G. A. 1895 Catalogue of the fishes in the British Museum. Second edition. Vol- ume first. British Mus. (Nat. Hist.), London, pp. i-xix, 1-391.

- 1904 Fishes. Systematic account of Teleostei. In: The Cambridge Natural History. Macmillan and Company, Ltd., London, pp. 539-760.

Day, A. L. 1914 The osseus system of Ophiocephalus striatus Bloch. Philippine Jour. Sci, 9: $19-56$.

Gregory, W. K. 1933 Fish skulls: A study of the evolution of natural mechanisms. Trans. Amer. Philo. Soc., N. S., 23: part 2: i-vii, 75481.

Katayama, M. 1959 Studies on the serranid fishes of Japan (1). Bull. Fac. Educ., Yamaguchi Univ., 8: 103-180.

1960 Fauna Japonica. Serranidae (Pisces). Tokyo News Service, Ltd., Tokyo, pp. i-vii, 1-189.

Norman, J. R. 1929 The teleostean fishes of the family Chiasmodontidae. Ann. Mag. Nat. Hist., III: 529-544.

1931 A history of fishes. Frederick A. Stokes, New York.

Smith, J. L. B. 1941 The genus Gymnocranius Klunzinger, with notes on certain rare fishes from Portuguese East Africa. Trans. Royal Soc. So. Africa, 28: part 2: 441-452.

Starks, E. C. 1904 The osteology of some berycoid fishes. Proc. U. S. Nat. Mus., 27 : 601-619.

Weisel, G. F. 1960 The osteocranium of the catostomid fish, Catostomus macrocheilus. A study in adaptation and natural relationship. J. Morph., 106: 109-129.

Weitzman, S. H. 1954 The osteology and the relationships of the South American characid fishes of the subfamily Gasteropelecinae. Stanford Ichth. Bull., 4: 213-263.

Woodward, A. S. 1895 Catalogue of the fossil fishes in the British Museum (Natural History). Part 3 , containing the actinopterygian Teleostomi of the orders Chondrostei (concluded), Protospondyli, Aetheospondyli, and Isopondyli (in part). British Mus. (Nat. Hist.), London pp. i-xlii, 1-544. 
PLATES 
PLATE 1

EXPLANATION OF FIGURES

1 Representative Circumorbital Bones of Fishes. A to $D$ in left lateral aspect. $E$ and $F$ in left lateral and dorsal aspects. (W. L. Brudon, del.)
A. Dapedium politum Leach (redrawn from Woodward, 1895).
B. Amia calva Linnaeus. UMMZ 175897-S.
C. Osteoglossum bicirrhosum Vandelli. UMMZ 177342-S.
D. Cyprinus carpio Linnaeus. UMMZ 171795-S.
E. Myripristis (?) microphthalmus Bleeker. UMMZ 177346-S.
F. Epinephelus guttatus (Linnaeus). UMMZ 172543-S. 


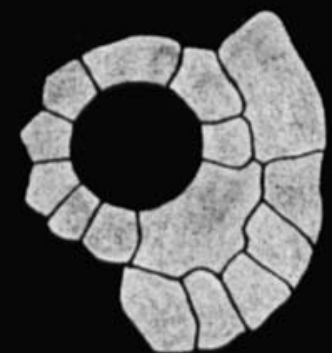

A
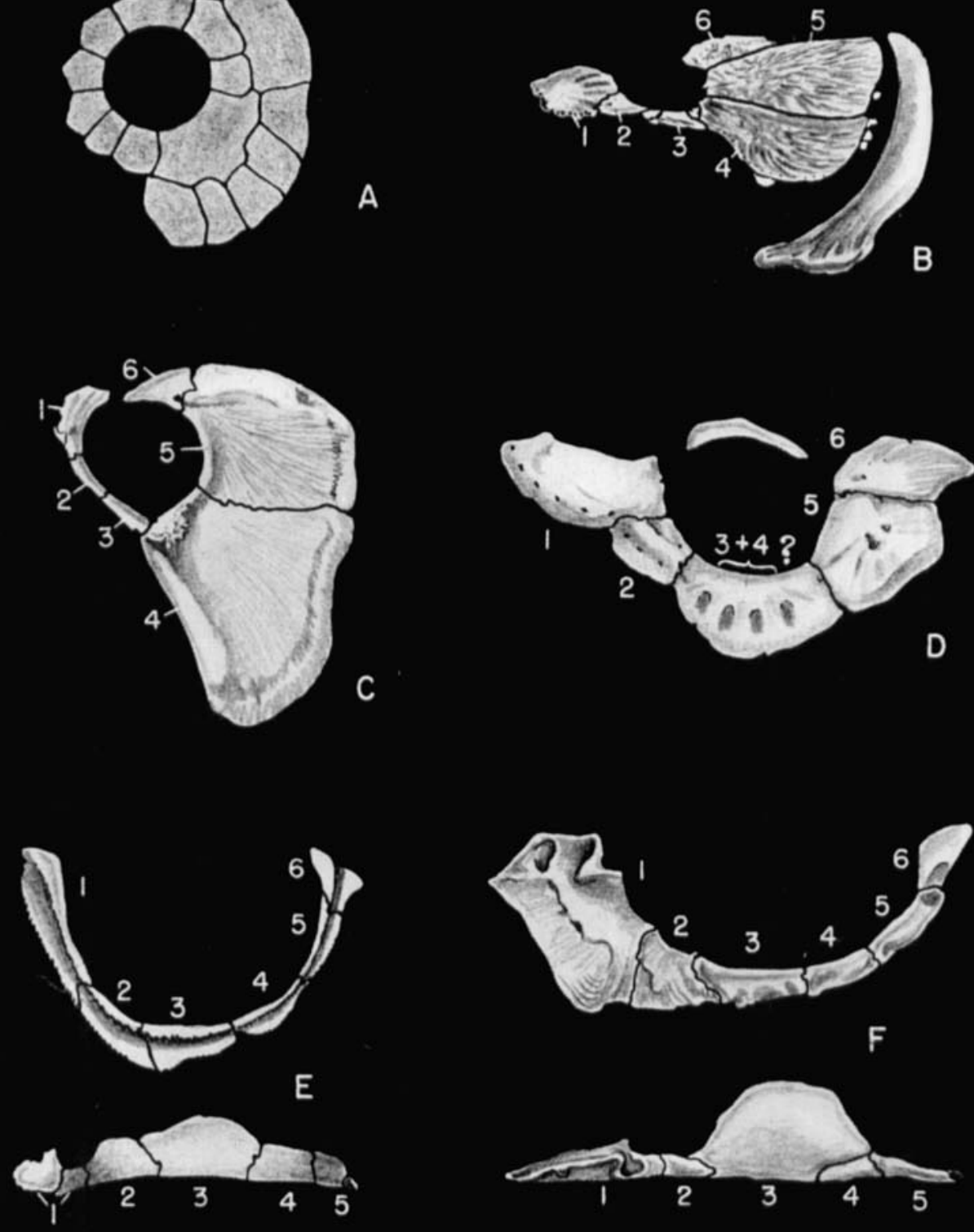
PLATE 2

EXPLANATION OF FIGURES

2 Suborbital Bones of Fishes. All shown in left lateral and dorsal aspects. (W. L. Brudon, del.)

G. Priacanthus arenatus Cuvier. UMMZ 173988-S.

H. Aplodinotus grunniens Rafinesque. UMMZ 147199-S.

I. Scatophagus argus (Bloch). UMMZ 177347-S.

J. Centropomus undecimalis (Bloch). UMMZ M59-31.

K. Calamus calamus (Valenciennes). UMMZ 142475.

L. Hypsypops rubicundus (Girard). UMMZ 176284-S. 


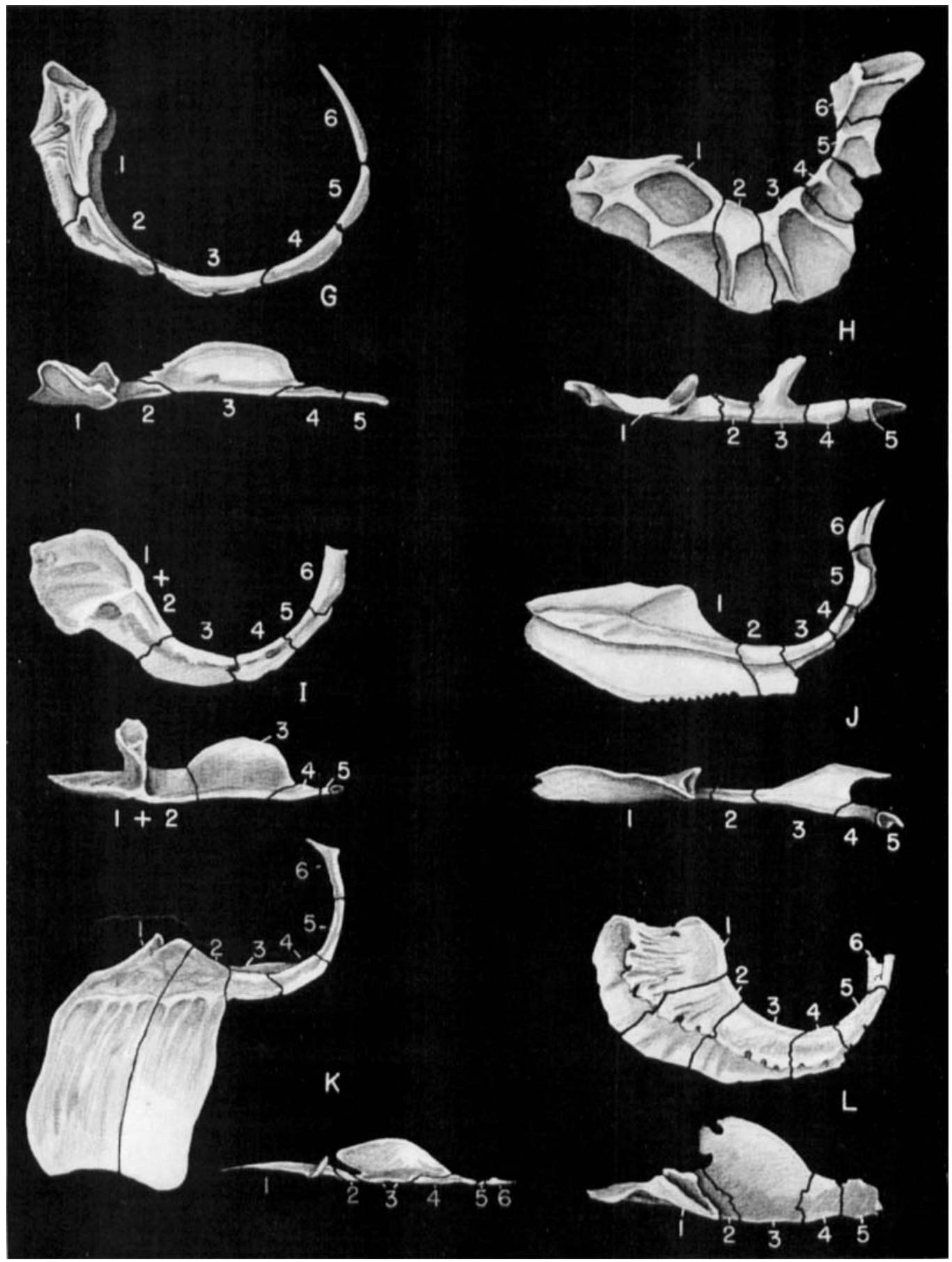


PLATE 3

EXPLANATION OF FIGURES

3 Suborbital Bones of Fishes. $M$ to $Q$ in left lateral and dorsal aspects. $R$ in left lateral and anterodorsal views. (W. L. Brudon, del.)

M. Micropterus salmoides (Lacépède). UMMZ 171793-S.

N. Pomoxis annularis Rafinesque. UMMZ 173469-S.

O. Haemulon sciurus (Shaw). UMMZ 173411-S.

P. Lutjanus blackfordi Goode and Bean. UMMZ 174137-S.

Q. Caranx lugubris Poey. UMMZ 177361-S.

R. Channa striata (Bloch). UMMZ 171840. 


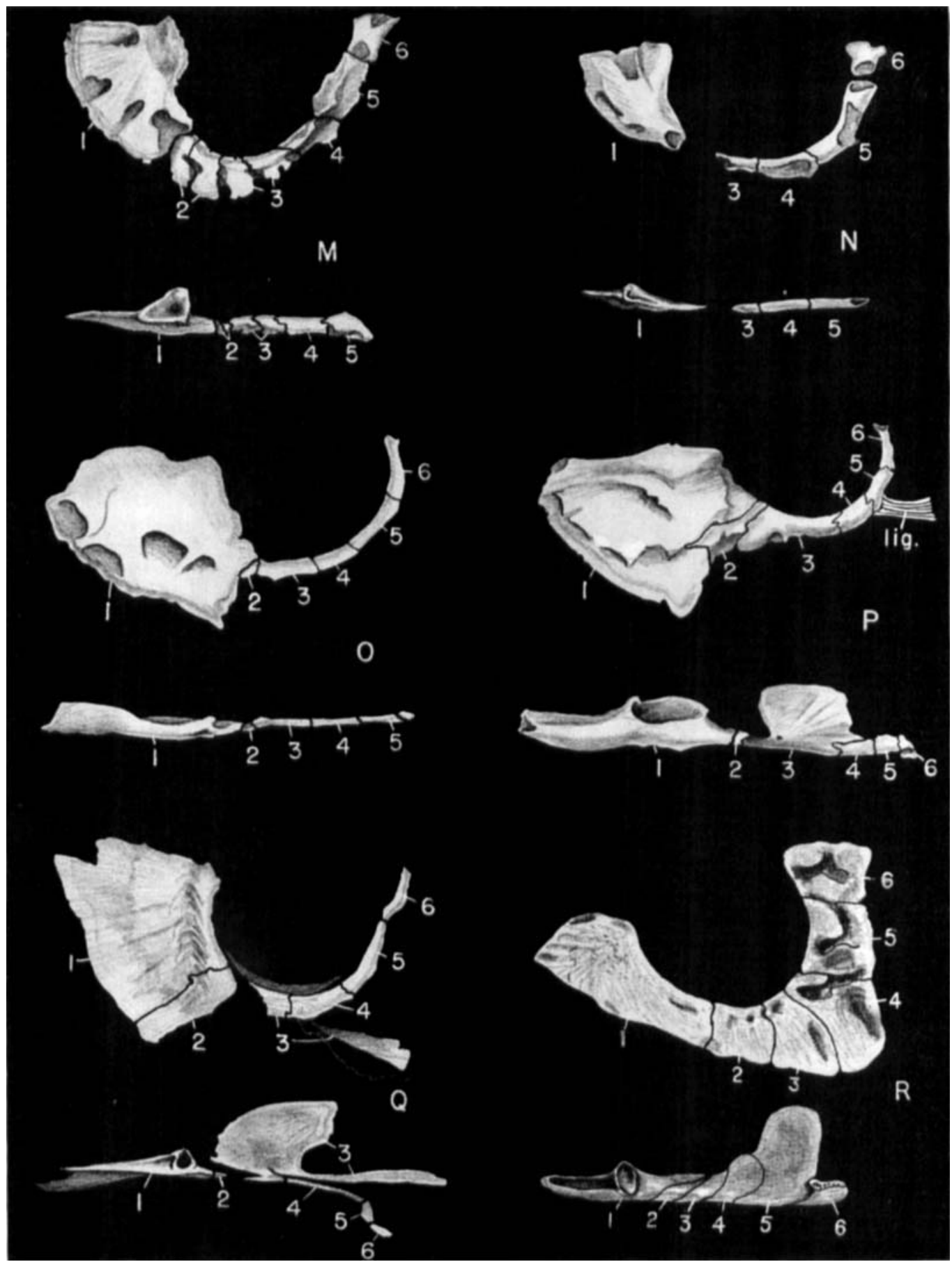

